apt to fluctuate depending on historical events. Religious motivations were apt to be overruled by foreign policy or local business interests. The situation only began to change in 1555 with the accession of Gian Pietro Carafa to the papal throne.

Such an example shows that this book presents a synthesis of social, historical, and cultural analysis. The editors themselves are fully aware of this characteristic of the work: "Notre travail se situe à mi-chemin entre la bibliographic, l'édition critique des sources et la monographie historique." This composite character is what differentiates this collection from the work of previous scholars, such as Franz Reusch, who studied the indexes. These volumes are the successful result of an effort by some of the greatest experts in this field to clarify the influence of censorship on Western life and culture. The editors deserve praise for what they have already achieved. This is a precious mine of information, an invaluable resource for consultation, and a series which will throw new light on the modus operandi of ecclesiastical censorship and its influence on the lives and minds of Renaissance people.

\title{
RITA BELLADONNA
}

York University

Luigi Monga and Chris Hassel, Travel Through France and Italy (1647-9). Geneva: Slatkine, 1987 (Biblioteca del Viaggio in Italia. Testi 25). Pp. 210.

Sir Thomas Palmer in An Fssay on the Meanes How to Make Trat'ailes into forraine Countries the more profitable and honourable (1606) identified five reasons to travel to the continent, especially to Italy: the climate; the attraction of studying at a good university; an education in manners; the opportunity to view several forms of government; and the archeological and historical remains. From the travel journal of the anonymous young Englishman and his party edited by Monga and Hassel, it is clear that this advice was well taken. The perspectives on the people and places recorded by the traveller indicate clearly that the company was abroad for its edification and for the broadening experience of foreign lands.

Although the author of the journal is unknown, his commentary reveals certain things about him, as Monga notes in his introduction. He was ccrtainly a royalist, choosing to avoid the horrors of the Civil War. Second he was an anglican in religion; indecd, I suggest he was verging on Roman Catholicism, given his close relations with religious houses, Jesuits and priests during his voyage.

The author exhibited the usual eclectic interest of early modern travellers. Knowledge of history and classical literature, together with an appreciation of art and, significantly, music, merge with a fascination with saints' relics and collections of curiosities which link these 17 th century travellers with the ancient pilgrimage tradition of the Middle Ages. In addition, there are recorded some popular etymologies of words and names that rival Isadore of Seville in their fancifulness.

The political, intellectual, artistic and religious concerns of the travellers are consequently of much interest because they provide an insight into the attitudes of the class they represented, attitudes focussed and distilled by the experience of expatriation. Thus, the rather specific and detailed historical observations made in France at the scenes of events which took place during the Wars of Religion have a particular application because of the events in England which the travellers were fiecing. And, 
it is indeed possible that their departure from Rome before the tumult broke out in 1649 as a result of the failure of the Monti Farnese (192) was determined because the Englishmen did not intend to escape one insurrection at home to suffer another abroad.

Finally, the character of the young man writing the journal is revealed tellingly. $\mathrm{He}$ is educated and concerned with learning, and his sense of irony is delicious. Two illustrations should suffice. When visiting the house of Cardinal Richelieu (not the great Richelieu but his brother) he notes: "Neere that Church is the Cardinalls house, where into wee found in his cabinet more dogges than bookes" (45). And later the diarist notes in a tone of tragic irony that their experiment in the Grotto del cane (Antro canino) did not work: the dog died and was not revived by the waters which "hath noe more power than ordinary water" (99).

This travel journal to France and Italy is therefore another useful addition to the series of texts on travel to Italy published under the direction of the Centro Interuniversitario di Ricerche sul 'Viaggio in Italia.' These books have made a fundamental contribution to the working scholar's knowledge of the sources of travel literature and the history of cultural contact with Italy. It is to be hoped that the various series and the Bollettino produced by C.I.R.V.I. continue indefinitely.

Once again, I must take exception to the eccentric arrangement of the notes which reduce their value in explicating the text. And, I must note some carelessness in proofreading (Sandy's for Sandys' twice, pp. 15, 16; knowlwdge for knowledge, p. 26; calles for called, p. 174; Thernae for Thermae, p. 191). Also, the tomb described by the diarist in the baptistry of San Giovanni in Florence is that the antipope John XXIII (Baldassare Coscia) not John III. This might be an error in transcription or a misreading by the author; but it is not caught in the notes. And, finally, I cannot agree with calling Il Mercurio Italico the first comprehensive English guide book to Italy: I suggest that honour should go to William Thomas' History of Italy (1549) which travellers for the next half century relied upon as their guide, as they did upon Thomas' Italian Grammar (1550) for the language.

Nevertheless, these minor exceptions aside, Monga and Hassel have provided the modern reader with an excellent text which will serve for some time to help enlighten that most important of all English continental cultural experiences, the giro d'Italia.

\section{KENNETH R. BARTLETT}

Victoria College, University of Toronto

Gian Piero Maragoni. L'onda e la spira. Saggio di ricerca sull'artificio anacronico nel "Conquisto di Granata" di Girolamo Graziani. Roma: Bulzoni, 1989 (Archivio Barocco). Pp. 69.

Quest'opera molto impegnativa (non tragga in inganno la misura breve) del giovane critico romano arricchisce la serie di volumi dell'Archivio Barocco, un progetto che coalizza diversi centri universitari italiani (Parma, Torino, Roma, Napoli) nel recupero capillare di testi rari, ben motivato dalla volontà di riattivare reagenti letterari quanto mai pertinenti all'attuale stagione culturale. Fedelissimo all'idea dell'Archivio, il Maragoni affronta un poema misconosciuto della metà del Seicento mettendone a fuoco, con un'analisi retorica puntigliosa, la regola compositiva. La quale si riassume 